\title{
Nýliðun lækna
}

Læknispjónusta er grunnstoð heilbrigðiskerfisins og stendur styrkum faglegum stoðum hérlendis. Í nýlegri sameiginlegri yfirlýsingu evrópskra læknasamtaka, sem birt er á öðrum stað í blaðinu (bls. 409), er lögð áhersla á lykilhlutverk lækna í sjúkdómsgreiningum, meðferð og pverfaglegri umönnun sjúklinga.

Stjórnvöld hafa kallað eftir samfélagsumræðu um skipulag heilbrigðiskerfisins en óljóst er hvert stefnir af peirra hálfu. Læknar hafa lýst sig reiðubúna í slíkt samtal.

Læknafélag Íslands (LÍ) leggur áherslu á prískiptingu sérhæfðrar heilbrigðispjónustu lækna í heilsugæslu og forvarnir, sérgreinapjónustu lækna utan sjúkrahúsa og á göngu- og dagdeildum og svo sjúkrahúspjónustu. Uppbygging, próun og fjárveitingar til pessara pjónustupátta eiga að haldast í hendur. Skipulag kerfisins verður að veita sveigjanleika til framfara í læknisfræði og aðgengi sjúklinga ásamt hagkvæmni og nýliðun.

Stefna LÍ hefur verið að styðja við fjölbreytileika í rekstri sérhæfðrar heilbrigðispjónustu utan sjúkrahúsa, hvort sem pað er hjá sérgreinalæknum á stofu eða í heilsugæslu, og telur mikilvægt að samkomulag um slíka pjónustu sé skýrt og samningar virtir. Á grundvelli pessara samninga hefur mikilvægum páttum í opinberu heilbrigðispjónustunni verið sinnt fram til pessa.

Almenningur er hlynntur einkarekinni sérhæfðri læknispjónustu utan sjúkrahúsa sem er samningsbundinn hluti af opinberri pjónustu. Petta má sjá í niðurstöðum skoðanakönnunar Rúnars Vilhjálmssonar fyrir BSRB frá 2015, par sem minnihluti, eða $40 \%$ aðspurðra, taldi að slíka pjónustu ætti eingöngu að veita af hinu opinbera en $60 \%$ voru hlynnt blönduðu kerfi eða eingöngu einkareknu. Hvort núverandi stjórnvöld ætla að ganga gegn meirihlutavilja pjóðarinnar og draga úr pjónustu við sjúklinga eða koma á tvöföldu heilbrigðiskerfi með pví að semja ekki við lækna á eftir að koma í ljós.

Eitt af lykilatriðum í jákvæðri framfarapróun í pessum geira er að tryggja nýliðun lækna og aðstreymi nýrrar pekkingar og reynslu. Đað er pví váleg staða pegar peim pætti er ógnað til lengri eða skemmri tíma. Starfandi læknar á Íslandi eru í dag 1296 og erlendis starfa 815 íslenskir læknar sem vonandi fá tækifæri til að starfa hérlendis í framtíðinni á peim vettvangi sem peir kjósa sjálfir og pörf er fyrir.
Nýliðun parf að eiga sér stað á öllum sviðum læknispjónustunnar. Á sama tíma og landsmönnum hefur fjölgað um 30.000 frá árinu 2010, hefur fastráðnum heilsugæslulæknum fækkað hjá öllum heilbrigðisstofnununum nema einni. Meðal annars hefur stöðugildum sem setin eru af sérfræðingum í heimilislækningum hjá hinu opinbera fækkað um 13\%, mest á landsbyggðinni, eða frá 5\% til 47\%. Hjá heilsugæslustöðvum í einkarekstri sem hið opinbera hefur náð að gera pjónustusamning við er staðan önnur en par starfa nú 29 sérfræðingar í heimilislækningum.

Á sjúkrahúsum hefur verið bent á að starfsaðstæður eru óviðunandi og álag á sjúkrahúslæknum á Landspítala er fram úr hófi á mörgum deildum, til dæmis bráđamóttökunni. Bráđalæknar hafa talað fyrir daufum eyrum allt frá nærstjórnendum upp í ráðuneyti. Par eru peir ekki einir á báti. Stöðuheimildum parf að fjölga og nýliðun parf að örva á sjúkrahúsum landsins. Pjónustuliðum verður ekki bætt par við án slíkra aðgerða.

LÍ leggur áherslu á að aðgengi að faglegri pekkingu lækna sé ætíð tryggt og til staðar í landinu, par með talið með samfelldri nýliðun lækna. Að fram fari mat á mannaflapörf lækna á öllum sviðum sérgreinalækninga, par með talið heimilislækna og á meðal almennra lækna. Tryggja parf að sérhæfð læknapjónusta sé áfram veitt utan sjúkrahúsa með samningum um opinbera pjónustu sérgreinalækna á eigin læknastofum og heilsugæslustöðvum. Endurskoða parf kjör landsbyggðarlækna með stjórnvaldsátaki. Styrkja parf pjónustu sérfræðilækna og bæta vinnuaðstæður á Landspítala og öðrum sjúkrahúsum með auknum framlögum í fjárlögum ríkisins. Að verkefni hvers pjónustuaðila séu vel skilgreind og endurskoðuð með parfir skjólstæðinga í fyrirrúmi. Að áhersla verði lögð á gæðastarf og leiðandi hlutverk lækna.

\section{Heimildir}

1. Sameiginleg yfirlýsing læknasamtaka í Evrópu. Um lykilhlutverk lækna í sjúkdómsgreiningu, meðferð og pverfaglegri umönnun sjúklinga. Læknablaðið 2018; 104: 422.

2. Heimilislæknar á Íslandi og ráoningar heilsugæslulækna á landsbyggð̀inni. 538. mál, fyrirspurn til heilbrigðisráðherra á 148. löggjafarbing 2017-2018. althingi.is/altext/148/s/1379.html - ágúst 2018.

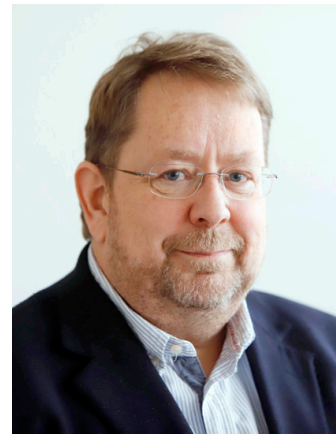

Reynir Arngrímsson

erfðalæknir, formaður Læknafélags Íslands

reynir@lis.is

\section{Continuous recruitment of doctors}

Reynir Arngrímsson MD, President of the Icelandic Medical Association

Hlíđasmára 8, 201 Kópavogi, Iceland

doi.org/10.17992//bl.2018.09.194 